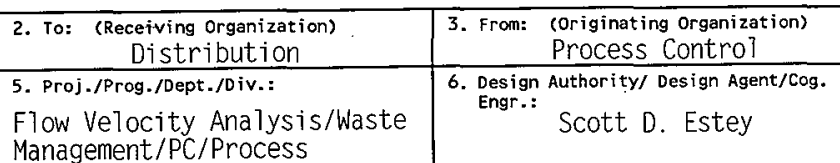

Engineering

8. Originator Remarks:

This document is-being released into the supporting document system for retrievability purposes.

11.. Receiver Remarks:- . 11A. Design Baseline Document? [] Yes [X] No

For release.

9. Equip./Component No.:

N/A

10. System/Bldg./Facility: N/A

12. Major Assm. Dwg. No.: N/A

13. Permit/Permit Application No.: N/A

14. Required Response Date: $10 / 08 / 98$

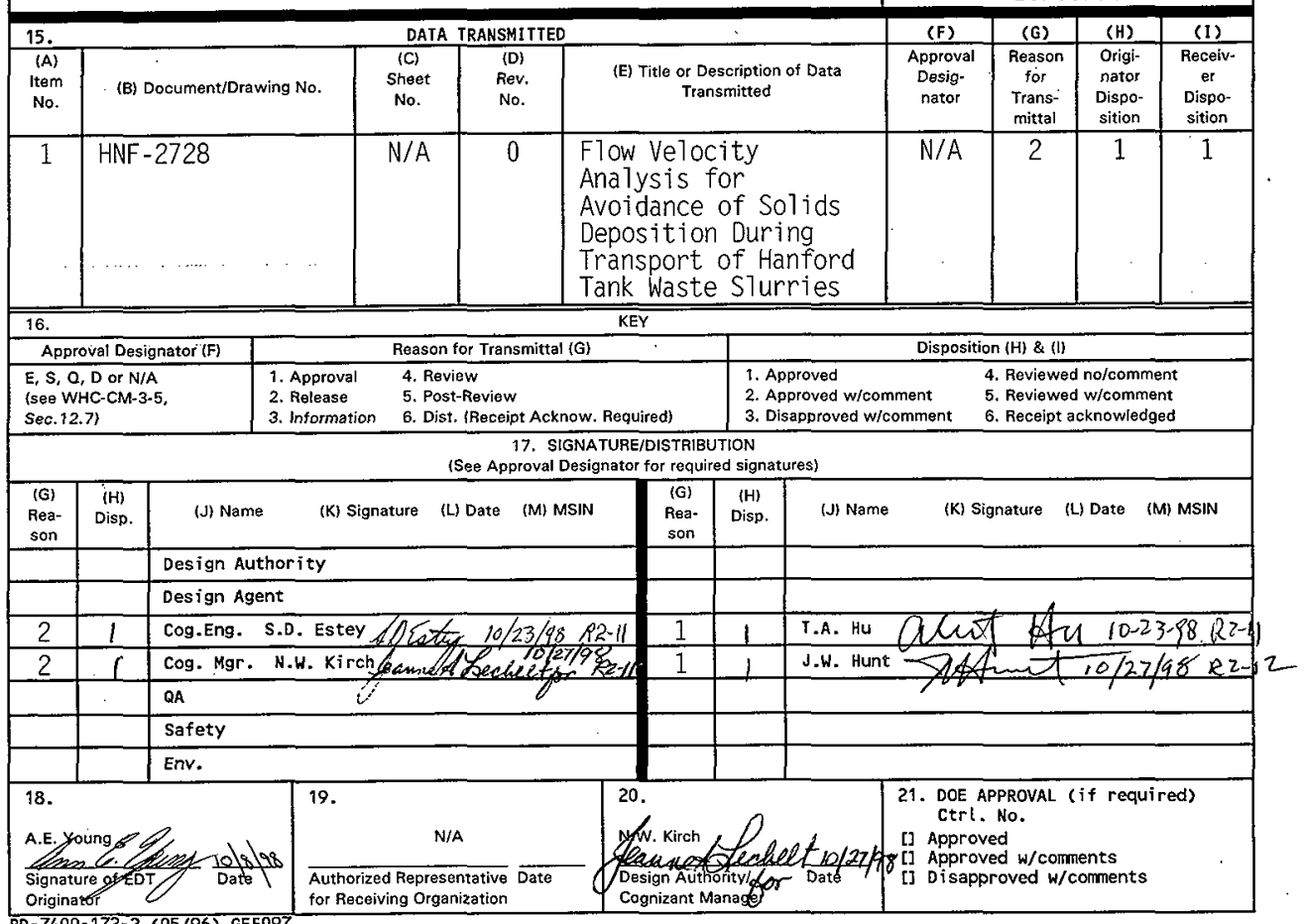

BD-7400-172-2 (05/96) GEF097 


\section{Flow Velocity Analysis for Avoidance of Solids Deposition During Transport of Hanford Tank Waste Slurries}

Scott D. Estey

Lockheed Martin Hanford Corp., Richland, WA 99352

U.S. Department of Energy Contract DE-AC06-96RL13200

EDT/ECN: EDT-622482

Org Code: $74 \mathrm{~B} 50$

B\&R Code: EW 3120074 Total Pages: 44

Key Words: Flow Velocity Analysis, Flow Velocity, Flow, Velocity, Analysis, Solids Deposition, Transport, Hanford, Tank Waste, Slurry, Slurries

Abstract: $N / A$

TRADEMARK DISCLAIMER. Reference herein to any specific commercial product, process, or service by trade name, trademark, manufacturer, or otherwise, does not necessarily constitute or imply its endorsement, recommendation, or favoring by the United states Government or any agency thereof or its contractors or subcontractors.

Printed in the United States of America. To obtain copies of this document, contact: Document Control Services, P.O. Box 950, Mailstop H6-08, Richland WA 99352, Phone (509) 372-2420; Fax (509) 376-4989.

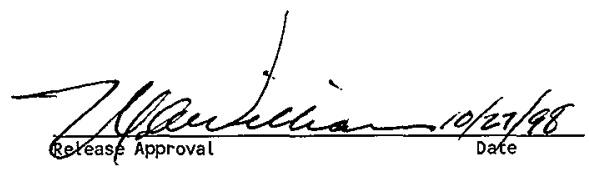

Approved for Public Release 
HNF-2728

Revision 0

\section{Flow Velocity Analysis \\ For Avoidance of Solids Deposition \\ During Transport of Hanford \\ Tank Waste Slurries}

S. D. Estey

T. A. Hu

Lockheed Martin Hanford Corporation

Date Published

October 1998

Prepared for the U.S. Department of Energy

Office of Environmental Restoration and Waste Management 


\section{SUMMARY}

This engineering analysis calculates minimum slurry transport velocities intended to maintain suspensions of solid particulates in slurries. This transport velocity is also known as the slurry flow critical velocity. It is not universally recognized that a transfer line flow velocity in excess of the slurry critical velocity is a requirement to prevent solids deposition and possible line plugging. However, slurry critical velocity seems to be the most prevalent objective measure to prevent solids deposition in transfer lines.

The following critical velocity correlations from the literature are investigated: Durand (1953), Spells (1955), Sinclair (1962), Zandi and Gavatos (1967), Babcock (1968), Shook (1969), and Oroskar and Turian (1980). The advantage of these critical velocity correlations is that their use is not reliant upon any measure of bulk slurry viscosity. The input parameters are limited to slurry phase densities and mass fractions, pipe diameter, particle diameter, and viscosity of the pure liquid phase of the slurry. Consequently, the critical velocity calculation does not require determination of system pressure drops. Generalized slurry properties can, therefore, be recommended if the slurry can be adequately described by these variables and if the liquid phase viscosity is known. Analysis of these correlations are presented, indicating that the Oroskar and Turian (1980) models appear to be more conservative for smaller particulate sizes, typically those less than 100 microns diameter.

This analysis suggests that the current Tank Farms waste compatibility program criteria may be insufficient to prevent particulate solids settling within slurry composition ranges currently allowed by the waste compatibility program. However, in order to relate a critical velocity associated with a certain slurry composition to a system limit, a means of relating the system capabilities to the slurry composition must be found. Generally, this means expressing the bulk or effective viscosity of the slurry being transferred to some more readily obtainable variable, such as slurry density or solids concentration. No universally recognized model exists to accomplish this, and there is great uncertainty among results from those models that do exist.

Following this analysis of critical velocity correlations, a recommendation is made to revise the waste transfer compatibility program criteria relating to solids transport. The new criteria states that a special engineering evaluation is required for any waste transfer that involves particulate solid transport. This evaluation is needed to gain a measure of confidence that the critical velocity for a given slurry composition is within the capabilities of the transfer system. 
HNF-2728 Rev. 0

This page intentionally left blank. 


\section{CONTENTS}

SUMMARY

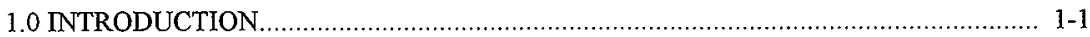

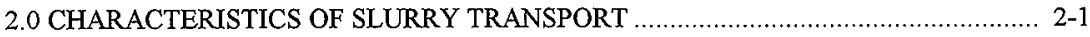

2.1 DESCRIPTIONS OF SLURRY PROPERTIES .................................................. 2-1

2.1.1 Solids Density and Concentration................................................................ 2-1

2.1.2 Liquid Viscosity ........................................................................... 2-3

2.1.3 Size of Solid Particulates........................................................................... 2-3

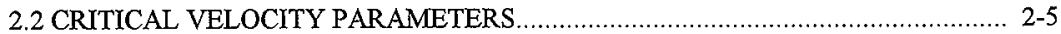

2.2.1 Particle Reynolds Number.................................................................. 2-5

2.2.2 Drag Coefficients for Settling Spherical Particles in Stokes Flow.................... 2-5

2.2.3 Terminal Velocity of a Spherical Particulate Solid in Stokes Flow ............. 2-6

2.2.4 Correction for Non-Stokes Flow ............................................ 2-6

2.3 SYSTEM SPECIFICATIONS.............................................. $2-7$

2.4 SUMMARY OF PARAMETERS REQUIRED FOR ANALYSIS …............ 2-8

3.0 CRITICAL VELOCITY CORRELATIONS .................................... 3-1

3.1 CORRELATIONS WITHOUT HINDERED SETTLING ........................ 3-1

3.2 CORRELATIONS INCLUDING HINDERED SETTLING...................... 3-2

4.0 RESULTS OF CRITICAL VELOCITY ANALYSIS ............................... 4-1

4.1 COMPARISON OF CRITICAL VELOCITY CORRELATIONS ................... 4-1

4.2 OROSKAR AND TURIAN (1980) EMPIRICAL CORRELATION CRITICAL VELOCITY .................................................................. 4-8

4.3 DISCUSSION .............................................................. $4-12$

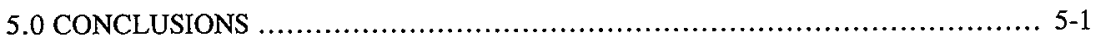

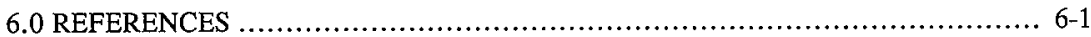




\section{FIGURES}

1.0 Hindered Settling Velocity Exponent Versus Particle Reynolds Number................ 3-4

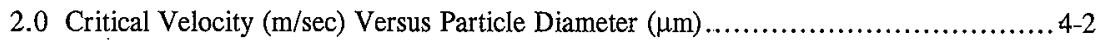

3.0 Critical Velocity (m/sec) Versus Solids Concentration (vol \%) for $100 \mu \mathrm{m}$ Particle ...... 4-3

4.0 Critical Velocity $(\mathrm{m} / \mathrm{sec}$ ) Versus Solids Concentration (vol\%) for $50 \mu \mathrm{m}$ Particle....... 4-4

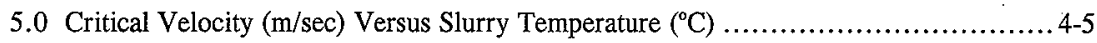

6.0 Critical Velocity $(\mathrm{m} / \mathrm{sec})$ Versus Carrier Liquid Density $(\mathrm{kg} / \mathrm{L}) \ldots \ldots \ldots \ldots \ldots \ldots \ldots \ldots . . \ldots \ldots$

7.0 Critical Velocity $(\mathrm{m} / \mathrm{sec})$ Versus Particulate Solid Density $(\mathrm{kg} / \mathrm{L})$.................. 4-7

8.0 Oroskar and Turian (1980) Empirical Correlation Critical Velocities ................... 4-9

9.0 Oroskar and Turian (1980) Empirical Correlation Critical Velocities ................ 4-10

10.0 Oroskar and Turian (1980) Empirical Correlation Critical Velocities................. 4-11

\section{TABLES}

2-1 Centrifuged Solids Density of Hanford Tank Waste.............................. 2-2

2-2 Volume Distribution for Particle Size Analysis of Hanford Sludges ................... 2-4 


\section{LIST OF ABBREVIATIONS}

$\begin{array}{ll}\mathrm{A} & \text { cross-sectional area of a spherical particulate solid } \\ \alpha_{\mathrm{c}} & \text { liquid phase volume fraction } \\ \alpha_{\mathrm{d}} & \text { particulate solid phase volume fraction } \\ \mathrm{C}_{\mathrm{D}} & \text { coefficient of drag } \\ \chi & \text { fraction of the turbulent fluid eddies that possess a velocity larger than the } \\ \mathrm{cP} & \text { particulate settling velocity from Oroskar and Turian (1980) } \\ \mathrm{D}_{\mathrm{d}} & \text { centi-poise } \\ \mathrm{D}_{\text {pipe }} & \text { particulate solid phase effective mean diameter } \\ \mathrm{F} & \text { internal pipe diameter } \\ \mathrm{g} & \text { weight of a particulate solid } \\ \gamma & \text { gravitational acceleration } \\ \mathrm{ID} & \text { dimensionless velocity of the turbulent fluid eddies within the pipe from } \\ \mathrm{in} & \text { Oroskar and Turian (1980) } \\ \mathrm{kg} & \text { internal diameter } \\ \mathrm{kg} / \mathrm{L} & \text { inch } \\ \mathrm{L} & \text { kilogram } \\ \mathrm{LMHC} & \text { kilogram per liter } \\ \mu_{\mathrm{c}} & \text { liter } \\ \mu \mathrm{m} & \text { Lockheed Martin Hanford Corporation } \\ \mathrm{n} & \text { liquid phase viscosity } \\ \mathrm{NHC} & \text { micrometer or micron } \\ \mathrm{N}_{\mathrm{I}} & \text { hindered settling velocity exponent } \\ \% & \text { Numatec Hanford Corporation } \\ \rho_{\mathrm{c}} & \text { Zandi and Gavatos (1967) decision factor } \\ \rho_{\mathrm{d}} & \text { percent } \\ \rho_{\mathrm{m}} & \text { liquid phase density } \\ \mathrm{psi} & \text { particulate solid phase density } \\ \mathrm{RCSTS} & \text { slurry density } \\ \mathrm{Re} & \text { pounds per square inch } \\ \mathrm{Re} \mathrm{p}_{\mathrm{particle}} & \text { Replacement Cross-Site Transfer System } \\ \mathrm{Re} & \text { Reynolds Number } \\ \mathrm{rpm} & \text { particle or relative Reynolds number } \\ \mathrm{T} & \text { pipe flow Reynolds number } \\ \mathrm{TWRS} & \text { revolutions per minute } \\ \mathrm{u}_{\mathrm{d}} & \text { temperature } \\ \mathrm{v}_{\mathrm{criti}} & \text { Tank Waste Remediation System } \\ & \text { characteristic velocity of a settling particulate } \\ \text { generic term for critical velocity } \\ \end{array}$




\section{LIST OF ABBREVIATIONS (Continued)}

\begin{tabular}{|c|c|}
\hline$V_{\text {durand }}$ & Durand (1953) critical velocity \\
\hline $\mathrm{V}_{\text {hindered }}$ & hindered terminal settling velocity of particulate solid \\
\hline $\mathrm{V}_{\text {ot_empirical }}$ & $\begin{array}{l}\text { Oroskar and Turian (1980) empirical or regression correlation critical } \\
\text { velocity }\end{array}$ \\
\hline $\mathrm{V}_{\text {ot_semi_theoretical }}$ & Oroskar and Turian (1980) semi-theoretical critical velocity \\
\hline$v_{\text {pipe }}$ & pipe flow velocity \\
\hline $\mathbf{y}_{\text {shook }}$ & Shook (1969) critical velocity \\
\hline $\mathrm{v}_{\text {sinclair }}$ & Sinclair (1962) critical velocity \\
\hline $\mathrm{V}_{\text {spells }}$ & Spells (1955) critical velocity \\
\hline $\mathrm{v}_{\mathrm{zg}}$ & Zandi and Gavatos (1967) critical velocity \\
\hline $\begin{array}{l}\mathrm{V}_{\infty} \\
\mathrm{vol} \%\end{array}$ & $\begin{array}{l}\text { unhindered terminal settling velocity of particulate solid } \\
\text { volume percent }\end{array}$ \\
\hline WRSS & Waste Retrieval Sluicing System \\
\hline${ }^{\circ} \mathrm{C}$ & degrees Centigrade \\
\hline${ }^{\circ} \mathrm{F}$ & degrees Fahrenheit \\
\hline
\end{tabular}




\subsection{INTRODUCTION}

Numatec Hanford Corporation (NHC) and Lockheed Martin Hanford Corporation (LMHC) have raised concerns that the Replacement Cross-Site Transfer System (RCSTS) may not meet pumping requirements for all proposed future waste slurry transfers. The analysis directed as a result is documented herein. The current Hanford Site Tank Waste Remediation System (TWRS) waste compatibility program requires that precautions be taken to prevent line pluggage during waste transfers. These criteria state that the pipeline flow be characterized by a Reynolds Number (Re) of greater than 20,000 and have no more than 30 volume percent particulate solids. For proposed transfers that do not meet these criteria, a special engineering evaluation is required to demonstrate that the transfer will not result in line plugging.

This engineering analysis examines certain parameters describing a slurry and estimates the conditions intended to avoid particle deposition during slurry transfer. The literature provides methods for estimating minimum velocities needed to maintain particulate suspension, typically known as the critical velocity, given knowledge of a sufficient amount of slurry physical properties. All of these correlations estimate the minimum pipe flow velocity required to maintain turbulent fluid forces high enough to overcome the gravitational force acting on a solid particulate. This velocity is also known as the critical velocity in slurry flow. A slurry flowing through a pipeline with a velocity greater than the critical velocity can usually be considered homogeneous. Homogeneous slurries are generally considered to consist of small particles kept in suspension by the turbulence of the carrier liquid. However, no slurry can be really considered completely homogeneous. A rule of thumb (Crowe et al. 1998) is that a homogeneous slurry is one in which the particulate concentration varies by less than $20 \%$ through the pipe cross section.

From a fluid mechanics standpoint, the slurry transport of Hanford tank waste is a challenge because of the compositionally complex and diverse nature of its constituents. One of the major complexities is that much tank waste contains appreciable amounts of insoluble submicron particles. These fine particles may stick together forming larger size agglomerates. Additionally, these larger agglomerates may network to form gel type materials that might plug transfer lines. The agglomeration kinetics is very sensitive to the $\mathrm{pH}$ value, temperature, or salt concentration. Several studies has been conducted regarding this colloidal effect in the Hanford tank waste (Rector and Bunker 1995, Liu et al. 1995, and Onishi et al. 1996) and the related issues will be discussed in the next sections. Since no simple engineering correlation exists to express this effect during slurry transport, the critical velocity analysis discussed below is based on simplified slurry properties. Prior to any critical velocity analysis, the slurry waste should be well characterized to identify the potential risk of the colloidal effect in the slurry transport. 
In the next sections, the characteristics of the slurry transport such as slurry properties, transport parameters, and specifications of pumping system will be discussed. Section 3 discusses various correlations of critical velocity from literature, and Section 4 presents the results of critical velocity analysis for a wide range of slurry properties. The summary and conclusions are presented in Section 5 . References cited in the report are listed in Section 6. 


\subsection{CHARACTERISTICS OF SLURRY TRANSPORT}

The slurry properties and transport system parameters govern the slurry transport behavior. The fundamental slurry properties, such as solids density, solids concentration, particle size, liquid density, and liquid viscosity, are discussed in Section 2.1. The development of critical velocity parameters are discussed in Section 2.2. A discussion of the assumed RCSTS design basis operating capabilities is given in Section 2.3.

\subsection{DESCRIPTION OF SLURRY PROPERTIES}

The various literature correlations for critical slurry flow velocities are usually expressed as functions of multiple independent variables, many of which are basic properties describing slurries. These properties are discussed in this section.

\subsubsection{Solids Density and Concentration}

To utilize these critical velocity correlations, it must be assumed that the slurry is composed of only two components: the liquid phase (also known as the carrier or continuous phase) and the solid phase (or dispersed phase). This is the usual assumption when dealing with slurry descriptions. Quantities that refer to the carrier phase are identified by the subscript " $\mathrm{c}$ ", while quantities that refer to the dispersed phase are identified by the subscript " $d$ ". Both carrier and dispersed phases are considered to have constant properties. The densities of each of the two phases are identified by $\rho_{d}$ and $\rho_{c}$, and the phase volume fractions are identified by $\alpha_{d}$ and $\alpha_{c}$.

In general, a larger density difference between the solid and liquid phase results in a higher critical velocity. A dispersed phase density of $3.0 \mathrm{~kg}$ per liter forms a reasonable, conservative, value of solid particulate densities to be found in typical Hanford tank wastes. Solid particulates with such densities would be composed of the various metallic oxides and hydroxides; precipitated salts would have a density closer to a value of $2.0 \mathrm{~kg}$ per liter. Another conservative assumption is that the liquid phase density is equal to that of pure water. The density of water is a function of temperature, but this effect is neglected since it varies only about $1 \%$ over the temperature range of $0^{\circ} \mathrm{C}$ to $100{ }^{\circ} \mathrm{C}$. Any higher density liquid, such as often found in concentrated salt solutions in the Hanford waste tanks, would result in a smaller density difference between the solid and liquid phases, thus requiring smaller velocities to maintain particle suspensions.

The sum of the two phase's volume fractions equals one. Therefore, if $\alpha_{d}$ is known, the value of $\alpha_{c}$ is also known.

$$
\alpha_{c}=\left(\mathrm{l}-\alpha_{d}\right)
$$


Knowing the volume fraction and density of each of the phases, the bulk density of the slurry is calculated simply by summing the products of volume fraction times the density of each phase. Any property that is referenced to the overall slurry is defined as a bulk property and is identified by the subscript " $m$ ". The bulk slurry density is $\rho_{m}$ :

$$
\rho_{m}=\alpha_{d} \rho_{d}+\alpha_{c} \rho_{c}
$$

or

$$
\rho_{m}=\alpha_{d}\left(\rho_{d}-\rho_{c}\right)+\rho_{c}
$$

Therefore, if $\rho_{d}$ and $\rho_{c}$ are specified, then $\rho_{m}$ becomes a function of $\alpha_{d}$. A $\rho_{m}$ value greater than $\rho_{c}$ indicates that both $\rho_{d}$ is greater than $\rho_{c}$ and $\alpha_{d}$ is greater than zero. For a given waste, the solid density, liquid density, as well as other slurry properties, are relatively fixed; thus, solids concentration is the main variable of concern. Usually, it is desired to control $\alpha_{d}$ to achieve the desired balance between transport efficiency and the probability of solids settling.

Typical insoluble solids in Hanford waste are identified as aluminum hydroxide (Gibbsite, Boehmite), iron hydroxides, and phosphate salts. The solids density of these particles range from 2.5 to $3.5 \mathrm{~kg} / \mathrm{L}$. Most of these particles are in the colloidal size range (i.e., less than 1 micron) and easily form agglomerates. As shown in Table 2-1, the observed bulk density of centrifuged solids from Hanford tank wastes range from 1.28 to $2.16 \mathrm{~kg} / \mathrm{L}$. This suggests agglomerate formation due to the lower observed densities; however, these data are not corrected for moisture content.

\begin{tabular}{|c|c|}
\hline Tanks: & Centrifuged Solla Density (kg) \\
\hline 241-AW-105 & $1.29-1.57$ \\
\hline 241-B-111 & $1.38-1.45$ \\
\hline 241-B-202 & $1.28-1.34$ \\
\hline 241-B-201 & $1.24-1.66$ \\
\hline $241-\mathrm{BX}-107$ & $1.49-1.58$ \\
\hline $241-C-110$ & $1.49-1.59$ \\
\hline $241-\mathrm{T}-102$ & 1.8 \\
\hline 241-T-104 & $1.30-1.52$ \\
\hline 241-T-105 & 1.56 \\
\hline $241-\mathrm{S}-104$ & 1.71 \\
\hline 241-SY-101 & $1.66-2.16$ \\
\hline
\end{tabular}

Table 2-1. Centrifuged Solids Density of Hanford Tank Waste 


\subsubsection{Liquid Viscosity}

It is assumed that the viscosity of the slurry liquid phase is equivalent to that of water. This assumption is conservative in that lower carrier liquid viscosities yield higher critical velocities. The viscosity of pure water is well known as a function of temperature. Since the viscosity of water decreases rapidly with increasing temperatures, velocity requirements will generally be more restrictive at higher temperatures. There exists evidence that the viscosity of any aqueous liquid phase will not differ greatly from that of pure water. Studies have indicated the viscosity is at most a factor of ten larger regardless of concentrations of dissolved sodium salts and caustic in the liquid (Zaltash and Ally 1992). For water (and the waste carrier liquid by assumption), viscosity is stated as the following function of temperature.

For temperatures in the range of $0{ }^{\circ} \mathrm{C}$ to $20^{\circ} \mathrm{C}$ (Weast and Astle 1980):

$$
\mu_{c}=100 * \exp \left[2.303 *\left(\frac{1301}{998.333+8.1855 *(T-20)+0.00585 *(T-20)^{2}}-3.30233\right)\right](c P)
$$

For temperatures in the range of $20^{\circ} \mathrm{C}$ to $100^{\circ} \mathrm{C}$ (Weast and Astle 1980):

$$
\mu_{c}=1.002 * \exp \left[2.303 *\left(\frac{1.3272^{*}(20-T)-0.001053^{*}(T-20)^{2}}{T+105}\right)\right](c P)
$$

\subsubsection{Size of Solid Particulates}

The particle size of the insoluble solids in the slurry suspension is one of properties that characterizes the slurry. This dimension certainly plays an important role in determining the particle Reynolds number, and many critical velocity correlations use it as an independent variable. In the critical velocity calculation, particle size is defined as the effective diameter of a spherical equivalent volume of the particle. In general, the larger the particles size the higher the settling velocity of the particle and the higher critical velocity of the slurry. Because of the compositional complexity of the wastes, the particle sizes in Hanford wastes range quite widely, from significantly submicron to several hundreds microns.

Much of the available characterization data for Hanford particulate solids indicate mass distributions typically in a range less than 50 microns (e.g., see Castaing 1994, Nguyen 1994, Edrington 1988, and Rodenhizer 1987). Some studies (Rector and Bunker 1995, and Liu et al. 1995) suggest that the particles with the diameters of less than one micron exhibit the behavior of colloidal aggregation and tend to form larger size agglomerates. This agglomeration process is sensitive to conditions such as $\mathrm{pH}$, temperature, salt concentration, and shear rate. This colloidal aggregation effect can change the rheological and sedimentation behavior of slurries (Rector and Bunker 1995). 
Table 2-1 lists particle size measurements of Hanford tank waste samples. As mentioned in Rapko et al. (1995), the samples were prepared for analysis by suspension in a 1:1 water/glycerin matrix, and it is unclear if this matrix yields an accurate measurement of the particle-size distribution that would be in encountered in an actual waste slurry. As shown in Onishi et al. (1996), the particle size measurements of the tank 241-SY-102 samples varies from 3.3 to $9.3 \mu \mathrm{m}$ volume-averaged mean depending upon solvent conditions. The results indicate that the agglomeration process changes the particle size under different chemistry conditions. Table $2-2$ provides an idea of the possible range of particulate sizes in Hanford wastes.

Table 2-2. Volume Distribution for Particle-Size Analysis of Hanford Sludges

\begin{tabular}{|c|c|c|c|}
\hline Tains & Mean $(\mathbf{m})$ & Rarge $(\mu \mathrm{m})$ & Data sources \\
\hline AN-104 & 5.68 & $0.7-19$ & Lumetta et al. 1997 \\
\hline B-106 & 3.64 & $0.2-6$ & Temer and Villarreal 1997 \\
\hline B-111 & 3.66 & $0.4-9$ & Rapko et al. 1995 \\
\hline BX-103 & 1.5 & $0.2-7$ & Temer and Villarreal 1997 \\
\hline BX-107 & 5.67 & $0.4-35$ & Rapko et al. 1995 \\
\hline BY-104 & 6.98 & $0.4-75$ & Lumetta et al. 1996 \\
\hline BY-108 & 6.53 & $0.2-39$ & Lumetta et al. 1997 \\
\hline BY-110 & 6.15 & $0.25-40$ & Lumetta et al. 1996 \\
\hline C-103 & 1.06 & $0.4-2$ & Rapko et al. 1995 \\
\hline C-104 & 2.05 & $0.2-7$ & Temer and Villarreal 1997 \\
\hline C-105 & 2.16 & $0.2-7$ & Temer and Villarreal 1997 \\
\hline S-101 & 6.8 & $0.29-38$ & Lumetta et al. 1997 \\
\hline S-104 & 6.78 & $0.2-30$ & Lumetta et al. 1997 \\
\hline S-107 & 13.48 & $0.35-100$ & Lumetta et al. 1996 \\
\hline S-111 & 47.7 & $0.9-120$ & Lumetta et al. 1997 \\
\hline SX-108 & 12.8 & $0.2-112$ & Lumetta et al. 1996 \\
\hline SX-113 & 1.84 & $0.2-6$ & Temer and Villarreal 1997 \\
\hline SY-102 & 9.32 & $0.2-105$ & Onishi et al. 1996 \\
\hline SY-103 & 9.71 & $0.4-30$ & Rapko et al. 1995 \\
\hline T-104 & 4.85 & $0.4-13$ & Rapko et al. 1995 \\
\hline T-111 & 4.82 & $0.4-12$ & Rapko et al. 1995 \\
\hline
\end{tabular}




\subsection{SLURRY TRANSPORT PARAMETERS}

Some basics of the fluid mechanics of slurry flow are required to utilize the various literature correlations for critical velocity for slurry flow. These parameters are discussed in this section.

\subsubsection{Particle Reynolds Number}

The Reynolds number relative to a settling particle is known as the particle Reynolds number $\left(\mathrm{Re}_{\mathrm{particl}}\right)$, and is used in defining drag coefficients for the particle. This Reynolds number describes a situation of external flow relative to the particle. The situation is equivalent to the carrier phase liquid flowing past a stationary particle at a velocity equal to the terminal settling velocity of the particle.

$$
\operatorname{Re}_{\text {paricle }}=D_{d} u_{\infty} \rho_{c} \mu_{c}^{-1}
$$

\subsubsection{Drag Coefficients for Settling Spherical Particles in Stokes Flow}

The drag coefficient $\left(\mathrm{C}_{\mathrm{D}}\right)$ is a dimensionless factor that relates the dynamic pressure $\left(\frac{1}{2} \rho_{c} v_{\infty}^{2}\right)$ of the fluid flowing around the particle to the induced frictional and pressure drag force $(F)$ on a particle:

$$
F=\frac{1}{8} C_{D} \pi D_{d}{ }^{2} u_{\infty}{ }^{2} \rho_{c}
$$

At terminal velocity, the drag force on the particle equals its weight (particle mass* gravity), or

$$
F=\frac{1}{6} \pi D_{d}^{3}\left(\rho_{d}-\rho_{c}\right) g
$$

Stokes Flow describes a situation where the drag force imparted by the moving fluid on the particle is caused only by viscous forces (force required to shear the fluid). The flow velocities are so low that the interial forces (the force needed to accelerate the fluid out of the path of the particle) are negligible. In Stokes Flow the particle drag coefficient is inversely proportional to the particle Reynolds number. The drag coefficient is defined as:

$$
C_{D}=24\left(\operatorname{Re}_{\text {paricle }}\right)^{-1}
$$


Solving Equation 7 for $\mathrm{C}_{\mathrm{D}}$ yields:

$$
C_{D}=8 F\left(\pi D_{d} \rho_{c} u_{\infty}^{2}\right)^{-1}
$$

When Equation 8 is substituted into Equation 10, the result is:

$$
C_{D}=\frac{4}{3} g D_{d} u_{\infty}^{-2}\left(\frac{\rho_{\delta}}{\rho_{c}}-1\right)
$$

\subsubsection{Terminal Velocity of a Spherical Particulate Solid in the Stokes Flow}

Many of the critical velocity correlations make use of the terminal velocity of an unhindered, spherical particle settling in the Stokes flow regime as an independent variable. The terminal settling velocity of a spherical particle in a quiescent fluid $\left(\mathrm{u}_{\infty}\right)$ in Stokes flow can be calculated by solving the drag coefficient relationship (Equation 7) for $\mathrm{u}_{\infty}$ :

$$
u_{\infty}=\sqrt{8 F\left[C_{D} \pi D_{d}^{2} \rho_{c}\right]^{-1}}
$$

When Equation 8 is substituted for $\mathrm{F}$ in Equation 12, rearrangement and simplification yields:

$$
u_{\infty}=\frac{D_{d}^{2}\left(\rho_{d}-\rho_{c}\right) g}{18 \mu_{c}}
$$

\subsubsection{Correction for Non-Stokes Flow}

When the particle Reynolds number at the terminal settling velocity is greater than 0.2 , inertial drag forces must also be considered in the total drag force on a particle. Stokes flow no longer applies in these cases. This Non-Stokes flow can become a significant factor for larger particles at terminal settling velocity since the drag coefficient becomes larger than the ratio (24/ $\left.\mathrm{Re}_{\text {particle }}\right)$. When the settling particulate cannot be considered in Stokes flow, the following value of $\mathrm{C}_{\mathrm{D}}$ (Shook and Roco 1991) applies for particle Reynolds numbers less than 1,500, which is the case in this analysis: 


$$
C_{D}=\left(\frac{24}{\operatorname{Re}_{\text {particle }}}\right)+3.5\left(\frac{1}{\mathrm{Re}_{\text {particle }}}\right)^{0.3}
$$

\subsection{SYSTEM SPECIFICATIONS}

RCSTS design parameters allow the system flowrate to be expressed as a function of pump speed and bulk slurry density. The system flow velocity in this analysis is that which can be provided by RCSTS. The system is briefly described as a 6.2 mile, 3 inch Schedule 40 , stainless steel pipe, containing two variable speed booster pump stations along the pipeline length to limit differential pressures in the pipe. It was a design assumption that the system experiences a maximum total pressure drop over its 6.2 mile length in the region of 1,000 to 1,200 psi. The power requirements to achieve a given flow velocity in the pipe are functions of the slurry density and viscosity since the pipe size and system configuration are established by the RCSTS. The specified design flow velocities had been recommended based upon slurry flow analysis (Place 1994; Sathyanarayana 1994).

The RCSTS operating regions, as defined by the intersections of the booster pump curves with the system curves, can be approximated as a linear relationship over the range of slurry densities and viscosities at a constant pump speed. The design slurry parameters for the RCSTS includes $\rho_{\mathrm{m}}=1.0 \mathrm{~kg} / \mathrm{L}$ at $\mu_{\mathrm{m}}=0.4665 \mathrm{cP}$ and $\rho_{\mathrm{m}}=1.5 \mathrm{~kg} / \mathrm{L}$ at $\mu_{\mathrm{m}}=30 \mathrm{cP}$ at the other. These slurry conditions correspond to specific flow velocities at a given pump speed. Since the slurry density is a linear function of the mass fraction of the dispersed phase, the RCSTS flow velocity (Calculation No. W058-P-048) can also be expressed as a linear function of the slurry density. Equation 15 indicates the slurry density-velocity relationship at a booster pump speed of $3,560 \mathrm{rpm}$.

$$
u_{\text {pipe }}=\left[2.286-0.916\left(\frac{\rho_{m}-\rho_{m_{-} \min }}{\rho_{m_{-} \max }-\rho_{m_{-} \min }}\right)\right]\left(\frac{\mathrm{m}}{\mathrm{sec}}\right)
$$

It should be emphasized that Equation 15 is arbitrary. Although the performance (i.e., the system flowrate versus pump speed) of the RCSTS system with water at $60^{\circ} \mathrm{C}\left(140^{\circ} \mathrm{F}\right)$ is well established, the performance of the RCSTS with various slurry compositions is not. The system performance with fluids other than water (i.e., slurries) are based on arbitrarily assumed relationships between the fluid density and fluid viscosity. These operating curves also assume that the fluids are Newtonian (i.e., exhibit no dependence on shear rate, or time of shear rate application). These assumptions are not good ones when dealing with slurries derived from Hanford wastes. A discussion of the difficulties in measuring and/or predicting the viscosities of Hanford waste mixtures is given by Herting (1981). 


\subsection{SUMMARY OF PARAMETERS REQUIRED FOR ANALYSIS}

\section{Slurry Parameters}

Liquid phase volume fraction $\left(\alpha_{c}\right)$

Liquid phase density $\left(\rho_{c}\right)$

Liquid phase viscosity $\left(\mu_{c}\right)$

Particulate solid phase volume fraction $\left(\alpha_{d}\right)$

Particulate solid phase density $\left(\rho_{\mathrm{d}}\right)$

Particulate solid phase effective mean diameter $\left(D_{d}\right)$
Pumping System Parameters

Internal pipe diameter $\left(D_{\text {pipe }}\right)$

Flow velocity ( $u_{\text {pipe }}$ ) 


\subsection{CRITICAL VELOCITY CORRELATIONS}

\subsection{CORRELATIONS WITHOUT HINDERED SETTLING}

Durand (1953):

$$
u_{\text {durand }}=1.5 \sqrt{2 D_{\text {pipe }} g\left(\frac{\rho_{d}}{\rho_{c}}-1\right)}
$$

Because the coefficient of drag $\left(C_{D}\right)$ does not appear in the equation, the Non-Stokes flow correction does not apply to the Durand (1953) correlation. Additionally, this correlation shows no particle size or fluid viscosity relationships.

Spells (1955):

$$
u_{\text {spells }}=\sqrt{0.025 \lg D_{d}\left(\frac{\rho_{d}}{\rho_{c}}-1\right)\left(\frac{u_{\text {spells }} D_{\text {pipe }} \rho_{m}}{\mu_{c}}\right)^{0.775}}
$$

This correlation is implicit in critical velocity. As in the Durand (1953) correlation, the Non-Stokes flow correction does not apply to the Spells (1955) correlation.

\section{Sinclair (1962):}

This correlation has the restriction that:

$$
\frac{D_{d}}{D_{\text {pipe }}}<0.001
$$

As a consequence, the Sinclair correlation applies only for particles less than $80 \mu \mathrm{m}$ diameter in a 3 inch internal diameter (ID) pipe:

$$
u_{\text {sinclair }}=\sqrt{650\left(\frac{4}{3} g D_{d}\right)\left(\frac{\rho_{d}}{\rho_{c}}-1\right)^{0.8}}
$$


As in the Durand (1953) correlation, the Non-Stokes flow correction does not apply to the Sinclair (1962) correlation.

\section{Zandi and Gavatos (1967):}

This critical velocity correlation is bounded by the pumping system requirement that the correlation decision criteria $\mathrm{N}_{\mathrm{I}}$, defined below, is greater than 40 :

$$
N_{I}=u_{p i p e}^{2} \sqrt{C_{D}}\left[\alpha_{d} D_{p i p e} g\left(\frac{\rho_{d}}{\rho_{c}}-1\right)\right]^{-1}
$$

If $N_{I}$ is greater than 40 , then

$$
u_{z a n d i_{-} \text {gavatos }}=\left[40 \alpha_{d} D_{p i p e} g\left(\frac{\rho_{d}}{\rho_{c}}-1\right)\right]^{\frac{1}{2}}\left[C_{D}\right]^{-\frac{1}{4}}
$$

The Zandi and Gavatos (1967) correlations explicitly incorporate the drag coefficient, allowing the non-Stokes Flow correction to be made.

Babcock (1968) reports an identical parametric dependence to that of Zandi and Gavatos (1967), but the critical velocity is equivalent to $\frac{1}{2} \mathrm{u}_{z a n d i}$ gavatos, so it will not yield a conservative result.

\section{Shook (1969):}

$$
u_{\text {shook }}=2.43 \alpha_{d}^{\frac{1}{3}} \sqrt{2 D_{\text {pipe }} g\left(\frac{\rho_{d}}{\rho_{c}}-1\right)}\left[C_{D}\right]^{-\frac{1}{4}}
$$

This correlation explicitly incorporates the drag coefficient, allowing the non-Stokes Flow correction to be made. 


\subsection{CORRELATIONS INCLUDING HINDERED SETTLING}

\section{Oroskar and Turian (1980):}

These correlations consider the affect of particle-particle interactions. If the number of particulate solids in the slurry is large, particle-particle collisions may significantly alter the motions of individual particles. The particle-particle interactions are another mechanism by which the solid particulates can exchange momentum and energy. These interactions can be thought of as increasing the effective viscosity of the "fluid", which is now a slurry as opposed to a pure liquid. As such, the "fluid" effectively exerts more drag on an individual particulate, increasing the drag coefficient and decreasing the critical velocity. This effect is commonly known as "hindered settling". Hindered settling was not considered in any of the earlier critical velocity correlations discussed.

This correlation utilizes a hindered settling velocity that is specified as a function of solids concentration:

$$
u_{\text {hindered }}=u_{\infty} \alpha_{d}{ }^{n}
$$

The hindered settling velocity exponent ( $n$ ) is stated in graphical form as a function of particle Reynolds number as experimentally determined by various earlier researchers. Specifically, $n$ takes on a value of 4.65 for particle Reynolds numbers less than 0.3 and a value of 2.33 for particle Reynolds numbers greater than 1000 . On a plot of $n$ as a function of the $\log _{10}$ of the particle Reynolds numbers, the transition is smooth and closely approximates that of the cumulative normal distribution with a mean of zero and a standard deviation of 0.5 .

$$
n=4.65-2.32\left[\frac{1}{\sqrt{0.5 \pi}} \int_{-\infty}^{\infty} \exp \left(-\frac{\left(\log _{10}\left(\operatorname{Re}_{\text {particle }}\right)\right)^{2}}{0.5}\right) d\left(\log _{10}\left(\operatorname{Re}_{\text {particle }}\right)\right)\right]
$$

A plot of the hindered settling velocity exponent is shown in Figure 1. 
Figure 1

Hindered Settling Velocity Exponent Versus Particle Reynolds Number

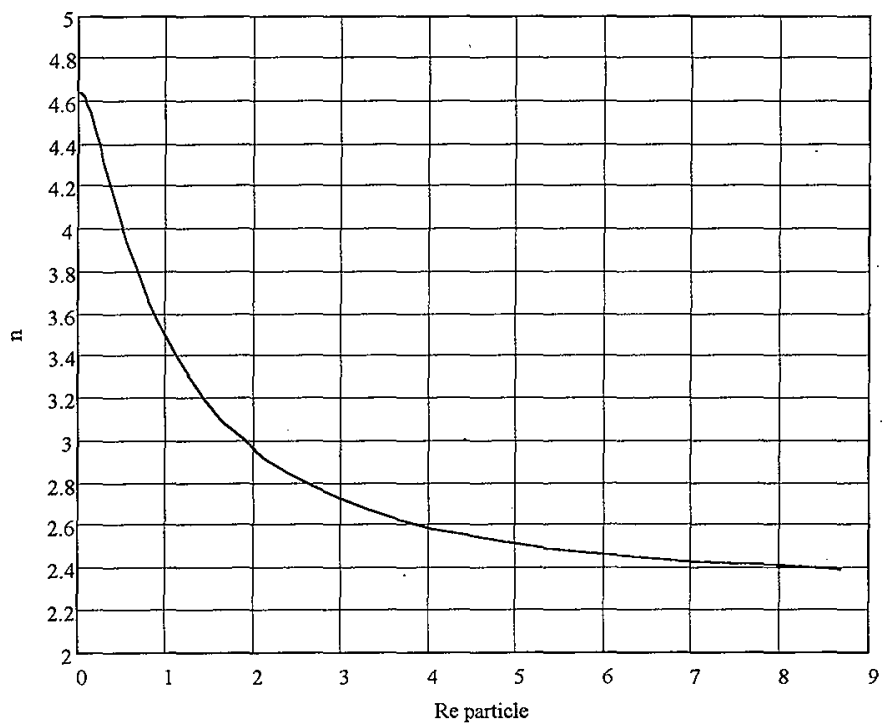

Oroskar and Turian (1980) developed a concept that considers turbulent fluid eddy velocity as the mechanism by which energy is provided to keep solid particulates suspended in solution. In the argument, $\gamma$ is the dimensionless velocity of the turbulent fluid eddies within the pipe, defined as the root mean square of the three-dimensional turbulent eddy velocity fluctuations. $\gamma$ is also defined as the ratio of particulate settling velocity to critical velocity. $\chi$ is that fraction of the turbulent fluid eddies possessing a velocity larger than the particulate settling velocity.

$$
\begin{aligned}
& \gamma=\frac{u_{\text {hindered }}}{u_{\text {critical }}} \\
& \chi=\frac{2}{\sqrt{\pi}} \gamma \exp \left(\frac{-4}{\pi} \gamma^{2}\right)+\left(1-\operatorname{erf}\left(\frac{2}{\sqrt{\pi}} \gamma\right)\right)
\end{aligned}
$$


The semi-theoretical and empirical data fit forms of the Oroskar and Turian (1980) correlation utilize the characteristic velocity of a settling particulate $\left(u_{d}\right)$,

$$
u_{d}=\sqrt{g D_{d}\left(\frac{\rho_{d}}{\rho_{\mathrm{s}}}-1\right)}
$$

Using $\mathrm{u}_{\mathrm{d}}$, the Oroskar and Turian (1980) correlations are defined:

$$
\begin{aligned}
& u_{\text {ot_semi_theoretical }}=u_{d}\left[5 \alpha_{d} \alpha_{c}^{(2 n-1)}\left(\frac{D_{\text {pipe }}}{D_{d}}\right)\left(\frac{D_{\text {pipe }} \rho_{c}}{\mu_{c}} u_{d}\right)^{\frac{1}{8}} \chi^{-1}\right]^{\frac{8}{15}} \\
& u_{\text {ot_empirical }}=1.85 u_{d} \alpha_{d}^{0.1536} \alpha_{c}^{0.3564}\left(\frac{D_{\text {pipe }}}{D_{d}}\right)^{0.378}\left(\frac{D_{\text {pipe }} \rho_{c}}{\mu_{c}} u_{d}\right)^{0.09} \chi^{0.3}
\end{aligned}
$$

Both semi-theoretical and empirical forms of the Oroskar and Turian (1980) correlations are implicit in critical velocity, since $\gamma$ is a function of the respective critical velocity. 
HNF-2728 Rev. 0

This page intentionally left blank. 


\subsection{RESULTS OF CRITICAL VELOCITY ANALYSIS}

This section presents the results of critical velocity calculations using the correlations of Spells (1955), Sinclair (1962), Zandi and Gavatos (1967), Shook (1969), and Oroskar and Turian (1980). Comparison of the critical velocities from these correlations is discussed in Section 4.1. Plots of critical velocity as a function of specific slurry properties are given in Figures 2 to 7 . Contour plots of critical velocity as a function of two slurry properties, using the Oroskar and Turian (1980) regression correlation, are given in Figures 8 to 10 in Section 4.2. Section 4.3 provides a discussion of the findings.

\subsection{COMPARISON OF CRITICAL VELOCITY CORRELATIONS}

As shown in Section 3.0, the critical velocity can be calculated as a function of slurry properties of solids density, solids concentration (or volume fraction), solids particulate size, liquid density, and liquid viscosity. Based on these slurry properties, the transport parameters such as particle Reynolds number (Equation 6), terminal velocity (Equation 12), and drag coefficient (Equation 13) are used in the critical velocity analysis. The range of slurry properties used in the analysis is based on Hanford waste data as discussed in Section 2.0. In the analysis, the unhindered particulate solids settling velocities are typically below $0.02 \mathrm{~m} / \mathrm{sec}$, and the particle Reynolds numbers are typically less than 10 .

As shown in Figures 2 to 7, a critical velocity of zero indicates that the conditions of the plot are outside the range of applicability for the respective correlation. Those correlations that use the unhindered particulate settling velocity, such as Zandi and Gavatos (1967), show a strong increase in critical velocity as particle size, slurry temperature and solids concentration increase. The critical velocities of the Oroskar and Turian (1980) correlations, which consider the hindered settling velocity as a function of solids concentration, change more slowly and with a decreasing rate as these quantities increase. For the variable of solids concentration, both Oroskar and Turian (1980) correlations reach maximum critical velocities at some solids concentration less than maximum. The effect of solids concentration on the Oroskar and Turian (1980) critical velocities is the logical outcome of the hindered settling effect they incorporate. The enhanced momentum and energy transfer mechanisms associated with particle-particle interaction tends to reduce the fluid velocity required to achieve critical velocity. In all cases the critical velocity is higher when slurry temperature, solids density, and particle size increase, and is lower when carrier liquid density decreases. 
HNF-2728 Rev. 0

Figure 2

Critical Velocity $(\mathrm{m} / \mathrm{sec})$ vs. Particle Diameter $(\mu \mathrm{m})$

$\left(D_{\text {pipe }}=3.068 \mathrm{in} ; \alpha_{d}=0.20 ; \rho_{d}=3 \mathrm{~kg} / \mathrm{L} ; \rho_{\mathrm{C}}=1 \mathrm{~kg} / \mathrm{L} ; \mathrm{T}=20^{\circ} \mathrm{C} ; \mu_{\mathrm{c}}=1 \mathrm{cP}\right)$

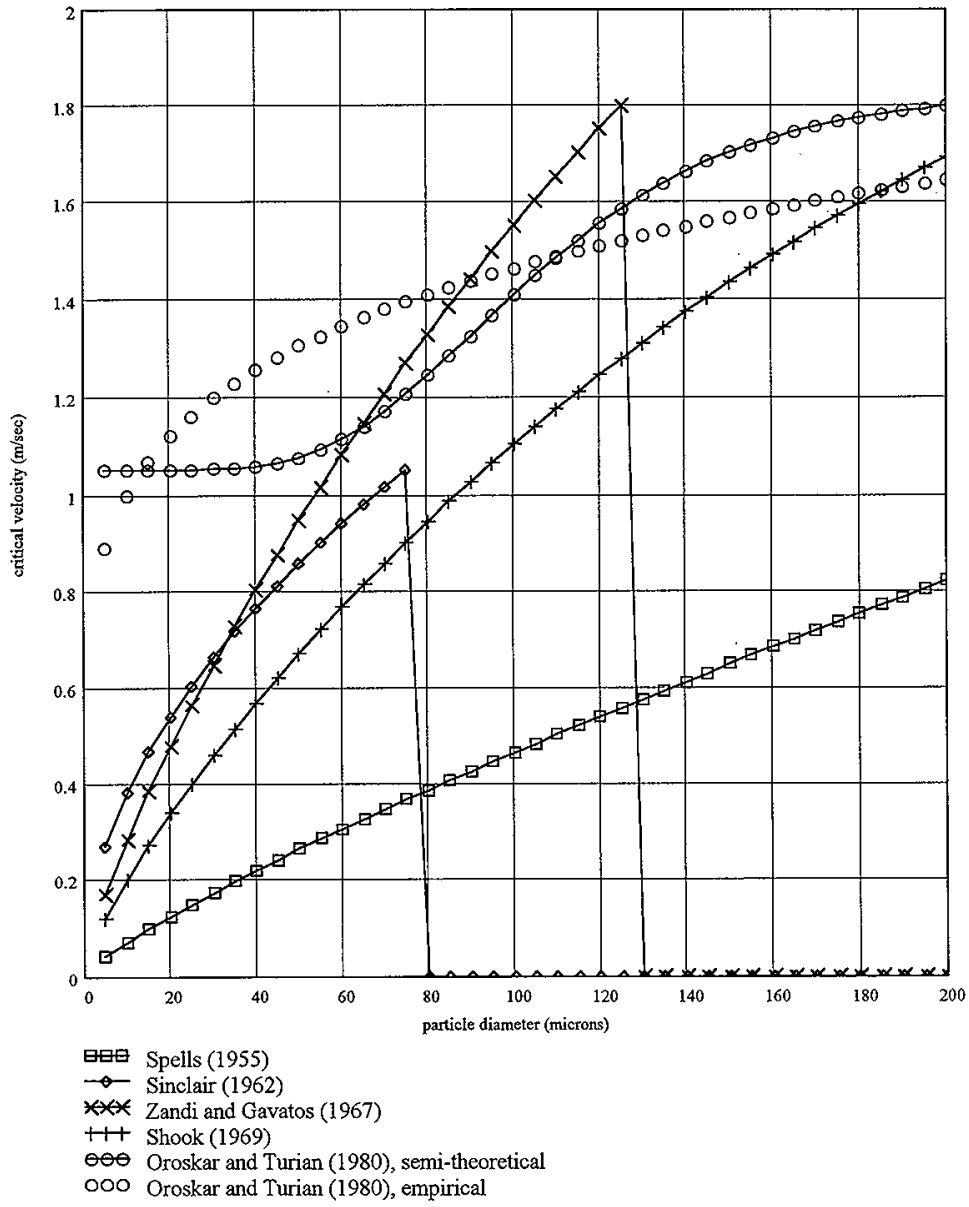


Figure 3

Critical Velocity ( $\mathrm{m} / \mathrm{sec}$ ) Versus Solids Concentration (vol\%) For $100 \mu \mathrm{m}$ Particle

$$
\left(D_{\text {pipe }}=3.068 \mathrm{in} ; D_{d}=100 \mu \mathrm{m} ; \rho_{\mathrm{d}}=3 \mathrm{~kg} / \mathrm{L} ; \rho_{\mathrm{c}}=1 \mathrm{~kg} / \mathrm{L} ; \mathrm{T}=20^{\circ} \mathrm{C} ; \mu_{\mathrm{c}}=1 \mathrm{cP}\right)
$$

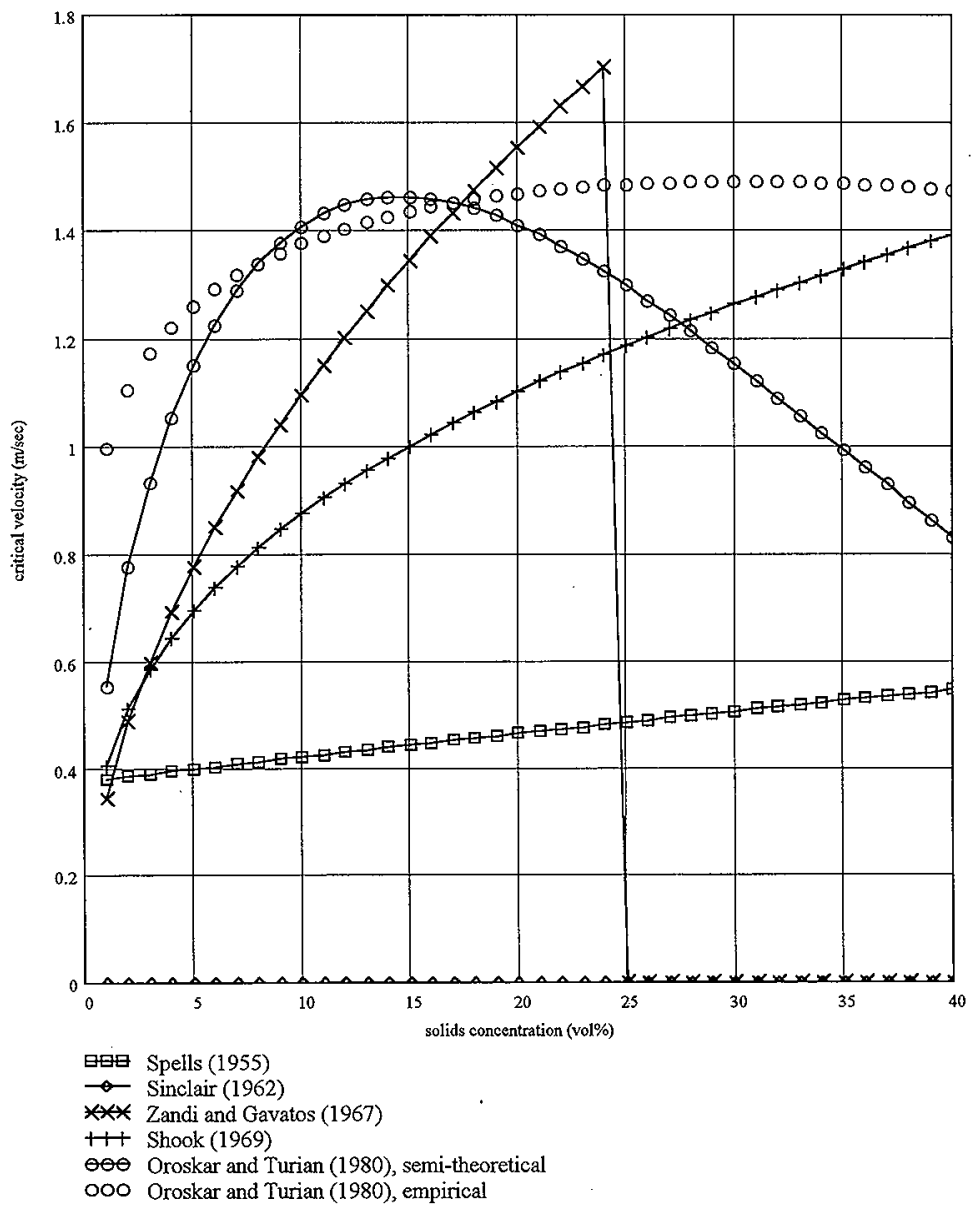


HNF-2728 Rey. 0

Figure 4

\section{Critical Velocity ( $\mathrm{m} / \mathrm{sec}$ ) Versus Solids Concentration (vol\%) For $50 \mu \mathrm{m}$ Particle}

$\left(D_{\text {pipe }}=3.068 \mathrm{in} ; D_{d}=50 \mu \mathrm{m} ; \rho_{\mathrm{d}}=3 \mathrm{~kg} / \mathrm{L} ; \rho_{\mathrm{c}}=1 \mathrm{~kg} / \mathrm{L} ; \mathrm{T}=50^{\circ} \mathrm{C} ; \mu_{\mathrm{c}}=0.457 \mathrm{cP}\right)$

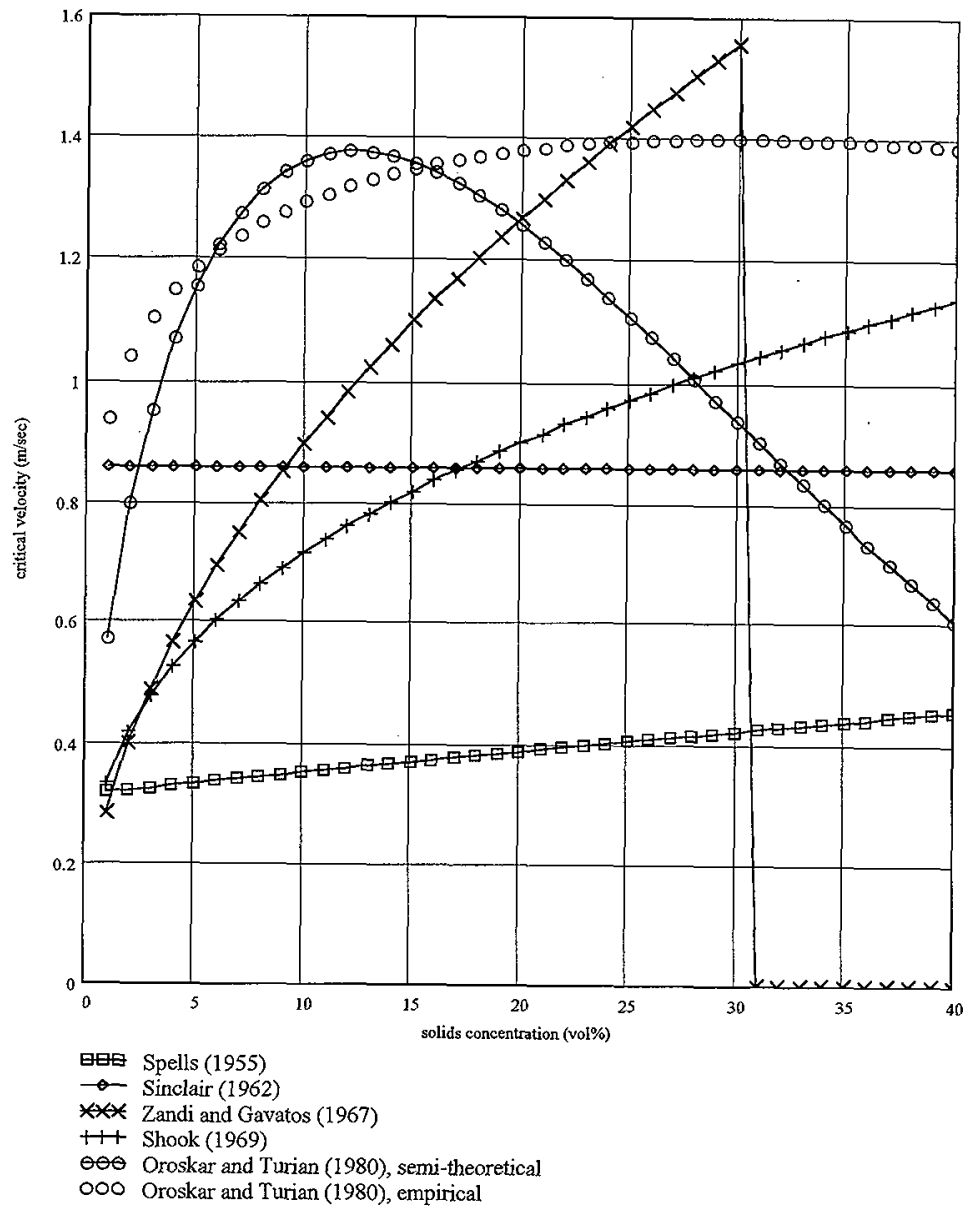


HNF-2728 Rev. 0

Figure 5

Critical Velocity $(\mathrm{m} / \mathrm{sec})$ Versus Slurry Temperature $\left({ }^{\circ} \mathrm{C}\right)$

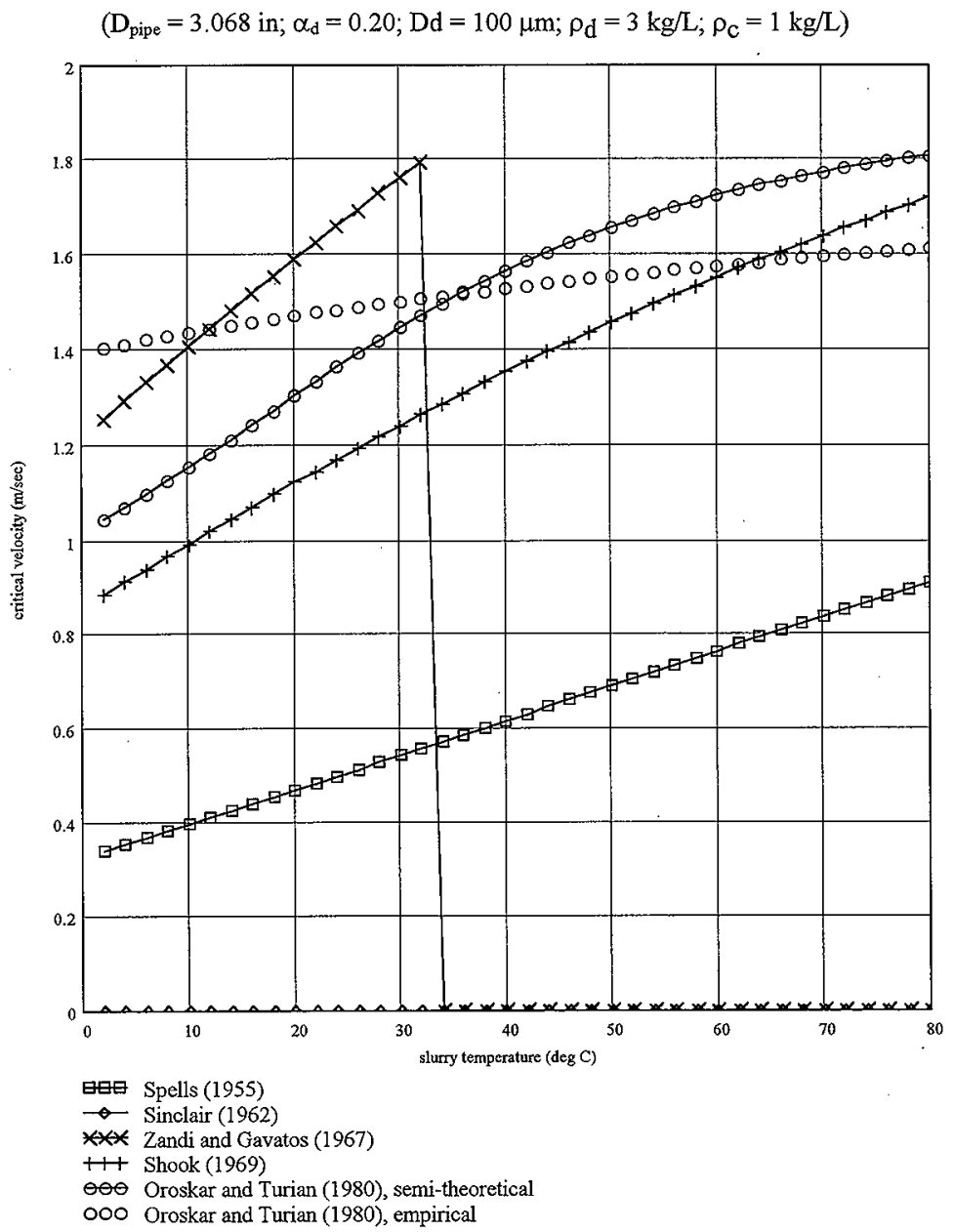


HNF-2728 Rev. 0

Figure 6

Critical Velocity (m/sec) Versus Carrier Liquid Density (kg/L)

$\left(D_{\text {pipe }}=3.068\right.$ in; $\left.\alpha_{d}=0.20 ; \mathrm{Dd}=100 \mu \mathrm{m} ; \rho_{\mathrm{d}}=2.25 \mathrm{~kg} / \mathrm{L} ; \mathrm{T}=20^{\circ} \mathrm{C} ; \mu_{\mathrm{c}}=1 \mathrm{cP}\right)$

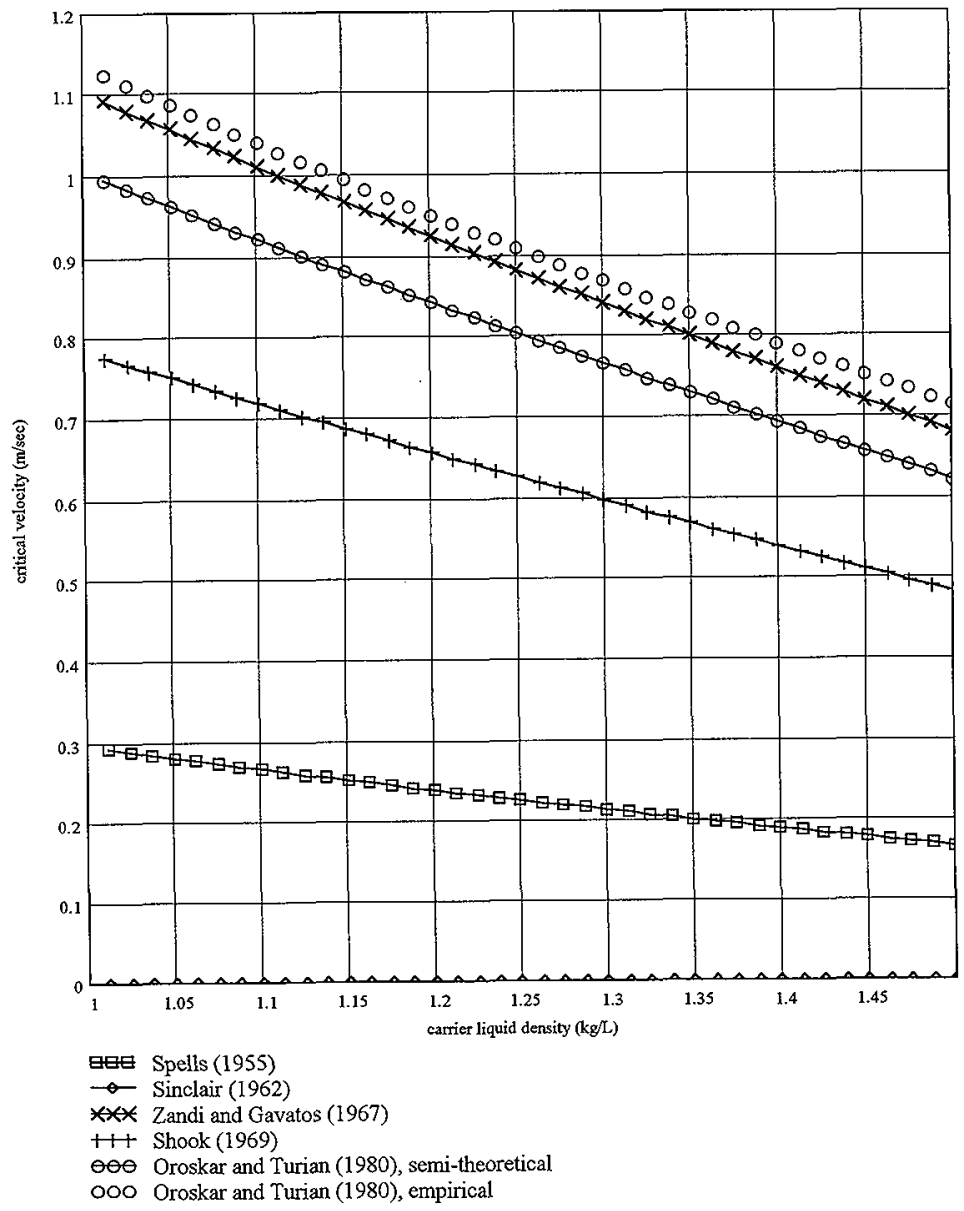


HNF-2728 Rev. 0

Figure 7

Critical Velocity (m/sec) Versus Particulate Solid Density (kg/L)

$\left(D_{\text {pipe }}=3.068 \mathrm{in} ; \mathrm{Dd}=100 \mu \mathrm{m} ; \rho_{\mathrm{c}}=1.25 \mathrm{~kg} / \mathrm{L} ; \mathrm{T}=20^{\circ} \mathrm{C} ; \mu_{\mathrm{c}}=1 \mathrm{cP}\right)$

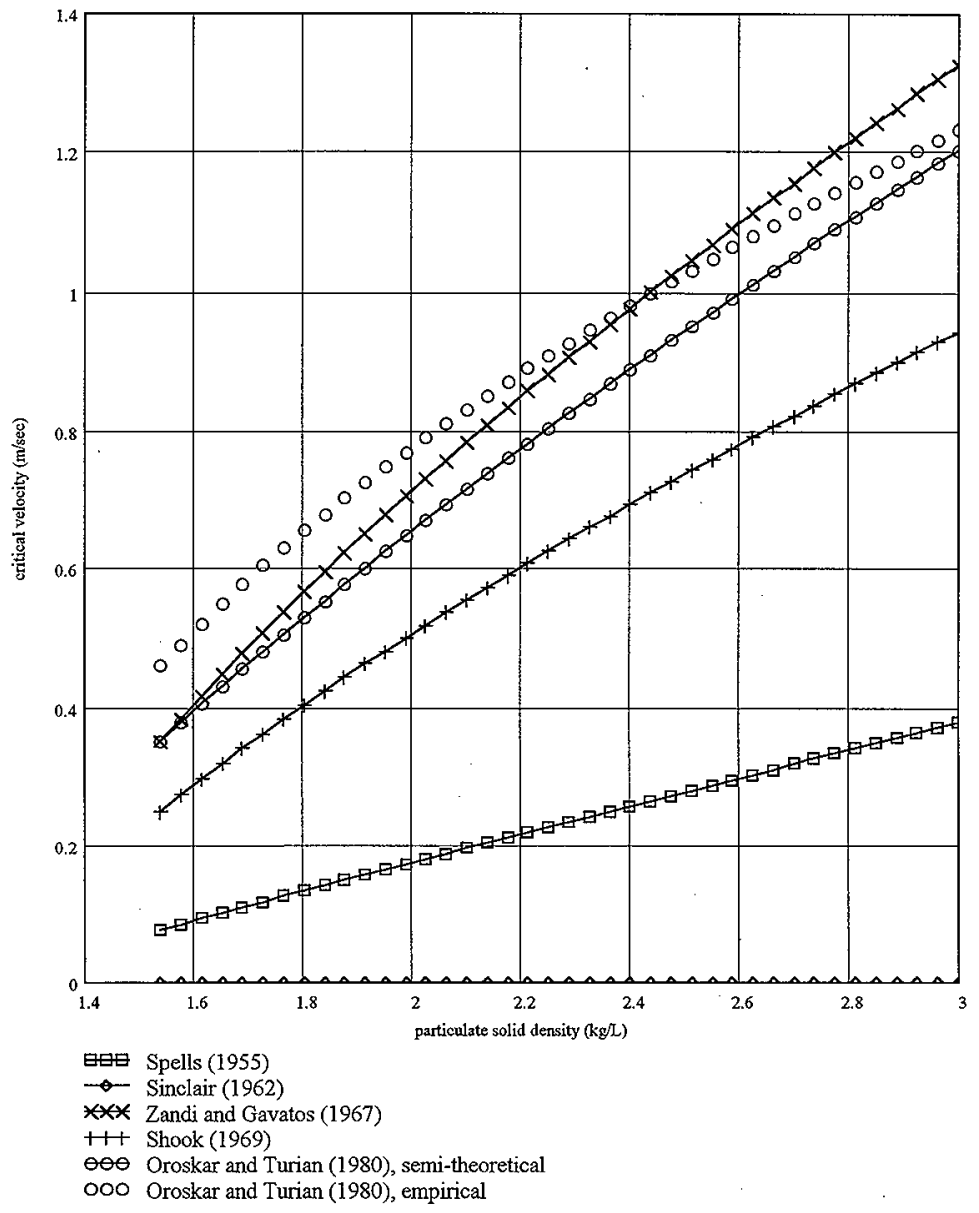


As shown in Table 2-2 in Section 2.0, the observed particle distribution for most Hanford tank wastes is well below 80 microns. The Oroskar and Turian (1980) correlations provide the most conservative critical velocity for particle diameters up to 80 microns and solids concentration below $20 \mathrm{vol} \%$ with the other given conditions as shown in Figure 2. The conservatism of the Oroskar and Turian (1980) correlations is also shown in Figures 3 and 4. The critical velocities of Oroskar and Turian (1980) are the most conservative among those correlations when the solids concentration is below $25 \mathrm{vol} \%$ and particle sizes are below $50 \mu \mathrm{m}$.

\subsection{OROSKAR AND TURIAN (1980) REGRESSION CORRELATION CRITICAL VELOCITY}

Although the Zandi and Gavatos (1967) correlation has previously been analyzed in an assessment of tank 241-SY-102 waste retrieval (Onishi and Hudson 1996; Onishi et al. 1996), the comparison of critical velocities shows that the Oroskar and Turian (1980) correlations seem more conservative than other models for the range of slurry properties expected to originate from typical Hanford wastes. Oroskar and Turian (1980) state that the overall percentage root mean square deviation of their regression correlation with 357 analyzed data points is $22 \%$. This is significantly better than the $59 \%$ of Zandi and Gavatos (1967), or $62 \%$ of Spells (1955). Using the regression correlation of Oroskar and Turian (1980), Figures 8 to 10 show critical velocity in contour plots as a function of two variable slurry properties. These plots help visualize the variable relationships in critical velocity calculations, and may help indicate the optimum balance between solids loading and prevention of solids deposition.

Figure 8 demonstrates the relationship between solids concentration and particle size. With the indicated constant properties, Figure 8 shows that critical velocity always increases with an increase in particle size, while again illustrating the hindered settling effect of solids concentration. The most restrictive solids concentration appears to be about 30 vol\%.

Figure 9 demonstrates the relationship between temperature and solids concentration with the other slurry conditions held constant as indicated. Figure 9 shows that critical velocity always increases with an increase in slurry temperature. The solids concentration effect is the same as in Figure 8

Figure 10 demonstrates the relationship between solids density and solids concentration with the other slurry conditions held constant as indicated. Figure 10 shows that critical velocity always increases with an increase in solids density. The solids concentration effect is the same as in Figure 8 
Figure 8

\section{Oroskar and Turian (1980) Empirical Correlation Critical Velocity}

contours: critical velocity $(\mathrm{m} / \mathrm{sec})$

vertical scale: particle diameter $(\mu \mathrm{m})$

horizontal scale: solids soncentration (vol\%)

$$
\begin{gathered}
\mathrm{D}_{\text {pipe }}=3.068 \mathrm{in} . \\
\mathrm{T}=20^{\circ} \mathrm{C} \\
\mu_{\mathrm{c}}=1 \mathrm{cP} \\
\rho_{\mathrm{d}}=3.0 \mathrm{~kg} / \mathrm{L} \\
\rho_{\mathrm{c}}=1.0 \mathrm{~kg} / \mathrm{L}
\end{gathered}
$$

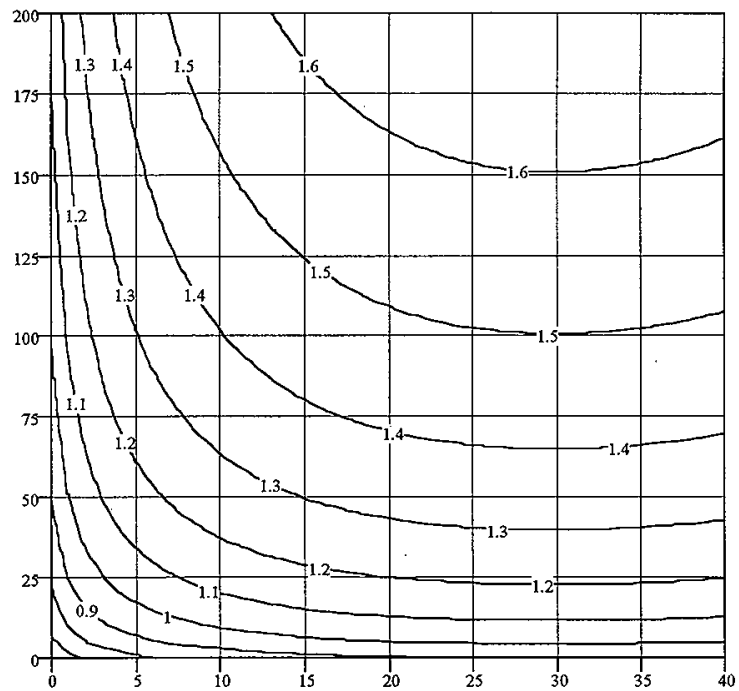

$\mathrm{u}$ critical 
HNF-2728 Rev. 0

\section{Figure 9}

\section{Oroskar and Turian (1980) Empirical Correlation Critical Velocity}

contours: critical velocity $(\mathrm{m} / \mathrm{sec})$

vertical scale: slurry temperature $\left({ }^{\circ} \mathrm{C}\right)$

horizontal scale: solids concentration (vol\%)

$$
\begin{gathered}
\mathrm{D}_{\text {pipe }}=3.068 \mathrm{in} . \\
\mathrm{D}_{\mathrm{d}}=100 \mu \mathrm{m} \\
\rho_{\mathrm{d}}=3.0 \mathrm{~kg} / \mathrm{L} \\
\rho_{\mathrm{c}}=1.0 \mathrm{~kg} / \mathrm{L}
\end{gathered}
$$

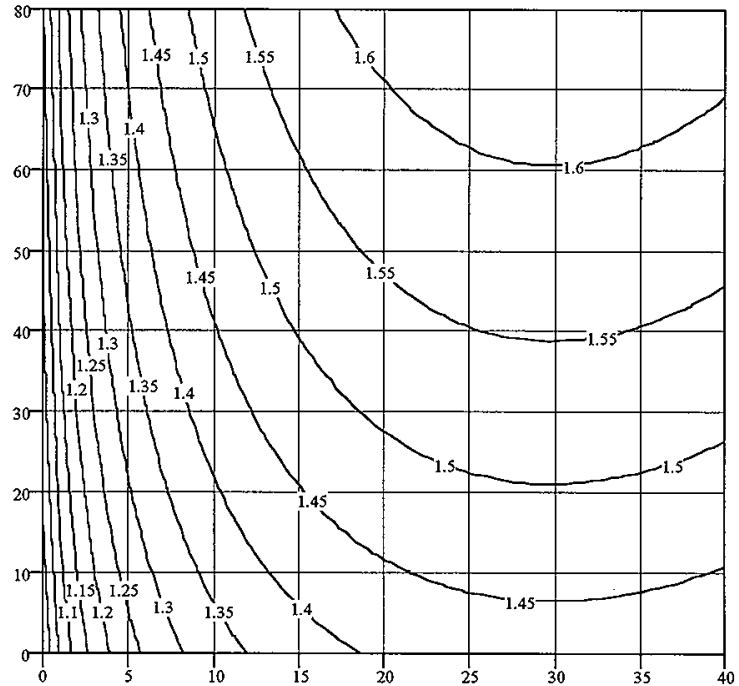

$u_{\text {critical }}$ 
Figure 10

\section{Oroskar and Turian (1980) Empirical Correlation Critical Velocity}

contours: critical velocity $(\mathrm{m} / \mathrm{sec})$

vertical scale: particulate solids density $(\mathrm{kg} / \mathrm{L})$

horizontal scale: solids concentration (vol\%)

$\mathrm{D}_{\text {pipe }}=3.068$ in

$\mathrm{D}_{\mathrm{d}}=100 \mu \mathrm{m}$

$\rho_{\mathrm{c}}=1.0 \mathrm{~kg} / \mathrm{L}$

$\mathrm{T}=20^{\circ} \mathrm{C}$

$\mu_{\mathrm{c}}=1 \mathrm{cP}$

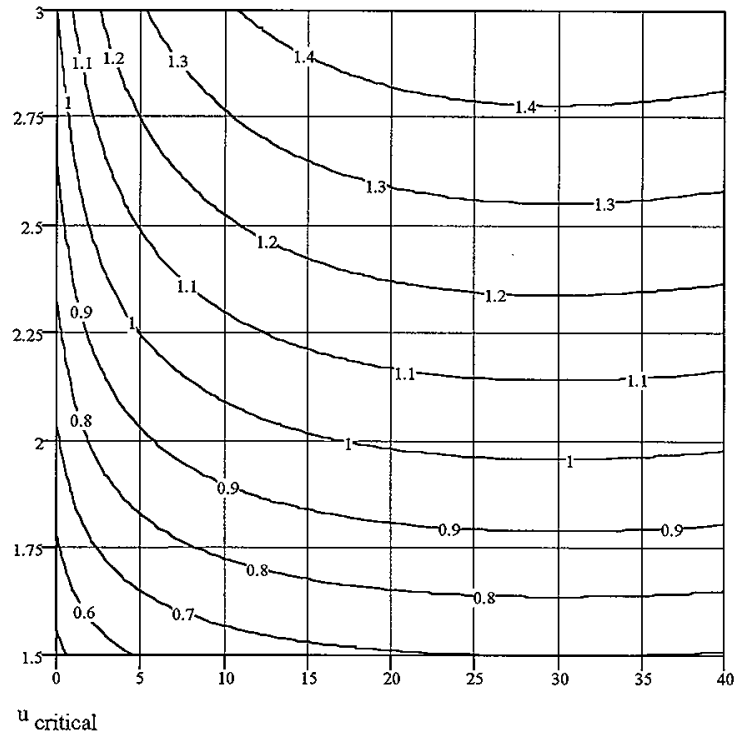




\subsection{DISCUSSION}

The Oroskar and Turian (1980) correlations, as well as most of the others, were developed from field data of coal, sand and gravel slurries. These slurries are different from the Hanford tank wastes, and if slurry flow critical velocity is a concern, more attention should be given to evaluating them using Hanford wastes.

The design of the RCSTS was based on arbitrarily assumed fluid and slurry properties. Specific to the RCSTS, the estimated slurry behavior was such that system flow velocity is less sensitive to fluid viscosity changes than is the calculated suspension velocity for particulate solids. Therefore, as liquid viscosity increases, the critical velocities calculated will decrease faster than the corresponding decrease in RCSTS flow velocity capability. However, it is unlikely that the actual properties of waste slurries to be transferred will closely resemble these assumed properties.

As an example, not considered by any of the referenced correlations is the effect of particulate shape on conditions of slurry homogeneity. In general, a more complex particulate shape of a given mass will exert a greater drag force on the carrier fluid, indicating that lower flow velocities would be required to maintain slurry homogeneity. On the other hand, more complex particulate shapes cause higher pressure drops and can form packed beds at lower densities than can nearly spherical particulates. In the extreme of complex particulate shapes, e.g., fractal agglomerates, it may be possible for the particulates to form a plug by means of an interlocking mesh or grid in the flow channel cross section at quite low dispersed phase concentrations. Such cases are very difficult to predict and may indicate that in complex chemical environments, standard slurry flow correlations are likely to be inappropriate.

The actual capabilities of the RCSTS can be predicted with certainty only if the physical properties of the slurry to be transferred are known with the same degree of certainty. The critical velocity correlations used in this analysis do not rely upon the effective bulk viscosity of the slurry being transferred, whereas the system pressure drop is fully dependent on this property. As a result, critical velocities of proposed slurry compositions can be estimated from tank waste characterization data, but the pressure drops resulting from the transport of such a slurry can only be measured in an actual pumping system operating with the actual slurry.

Measuring transport data resulting from slurry pumping allows the effective bulk viscosity of that slurry to be measured. One approach to accomplish this is to use simulated tank waste to measure the critical velocity in a slurry test loop facility and to determine the parametric relationships. However, there remains the question of how representative a simulant is to the actual waste slurry. Another approach is to use data generated by actual slurry transport operations, such as the tank 241-C-106 Waste Retrieval Sluicing System (WRSS). This system incorporates in-line slurry measurement capabilities that permit correlation of properties such as volumetric flowrates, mass flowrates, temperatures, and transfer line pressure drops (Carothers et al., 1998). The WRSS measurement capabilities will allow determination of the bulk slurry viscosity as a 
function of the various measured parameters. The design and operational data from the tank 241-SY-101 mixer-pump might also be used to directly determine the respective slurry rheological properties.

The system pressure drop is the function of the bulk flow Reynolds number, bulk velocity, friction factor, pipe diameter, and the pipe line equivalent length. The friction factor is a function of bulk flow Reynolds number while the pipe diameter and pipeline equivalent length are a characteristic of the piping system design. The bulk velocity might reasonably be set at some value in excess of the calculated critical velocity. However, the slurry viscosity needs to be determined, and this property is the greatest uncertainty in estimating the transport properties of any slurry. This quantity could be estimated by means of a relation which states that slurry viscosity is a function of solid concentration and a constant property liquid viscosity. Relations of this type have been proposed in the past (Ferrini et al. 1979; Einstein and Chien 1955). Hanford specific waste viscosity relationships have also been reported as functions of various parameters (Rodenhizer 1987; Reynolds 1988). However, any empirical slurry viscosity relationship usually is associated with a significant degree of uncertainty in determining the pressure drops of slurry flows.

If other Hanford waste slurries will exhibit properties similar to those generated from tank 241-C-106 waste retrieval, a method will exist to explicitly determine the relationship between the slurry critical velocity, the effective slurry viscosity, and the resulting system pressure drop. This would add significant confidence that transfer system flow velocity capabilities encompass the range of the slurry critical velocities.

From the viewpoint of critical velocity, the Oroskar and Turian (1980) correlations are the most recent, the most sophisticated, and yield the most conservative results over the range of slurry properties deemed most likely to originate from Hanford wastes. Other researchers have reached similar conclusions regarding available critical velocity correlations (Hudson 1996; Shah and Lord 1991). Comparing the two different Oroskar and Turian (1980) correlations, it seems that the regression model is more stable, and more conservative in the estimated region of application. For the given typical Hanford waste slurry properties the critical velocity requirement differs little from $1.5 \mathrm{~m} / \mathrm{sec}$ in a 3 inch ID pipe with solid concentrations on the order of 20 to 40 volume percent, particle diameters $<100 \mu \mathrm{m}$, and solid to liquid density ratios $<3.0$. It appears that the RCSTS facility can provide the necessary pressure drop to meet these critical velocity requirements. Additionally, The RCSTS provides the capability to install additional booster pumps to control maximum differential pressures while permitting increased system pressure drops. However, if larger particulate diameters and/or higher particulate densities occur, limitations may need to be placed on the allowable solids concentration/bulk density of the slurry. This indicates that a system capable of providing positive control over the slurry density within the pipeline may be a reasonable precaution against line plugging. 
HNF-2728 Rev. 0

This page intentionally left blank. 
HNF-2728 Rev. 0

\subsection{CONCLUSIONS}

This study has been an attempt to describe quantitatively the differences between slurries that are not susceptible to solids settling and those that are. The most common criteria for judging this behavior in the literature is the concept of slurry flow critical velocity. Critical velocity can be defined as the bulk flow velocity at which the fluid turbulence velocities impart drag forces on individual solid particles that exceed the particle weight, thus overcoming settling tendencies. This study examined eight documented correlations for critical velocity using the best-estimated properties of anticipated Hanford waste slurries. Even though the formulation of an exact quantitative description for predicting the desired slurry behavior is essentially impossible, general conclusions can be drawn.

Depending on the value of roughly a half dozen independent parameters describing a slurry, different correlations provide limiting suspension velocities applicable to slurry transfer through a three-inch internal diameter pipe. In the analyzed range of conditions the empirical or regression model of Oroskar and Turian (1980) provide the most conservative critical velocity estimate for the vast majority of particle size-slurry density combinations. All of the correlations show that an increase in carrier phase viscosity results in a decreased particulate suspension velocity. The same effect is noted for any conditions that decrease the density differences between the solid and liquid phases.

Although slurry flow critical velocity is intended to establish conditions that avoid solids deposition, some solids deposition does not necessarily equate to line pluggage. If the pumping system has capability in excess of the pressure drop associated with critical velocity, deposited solids should be re-suspended upon an increase in flowrate. Additional margin against line plugging derives from the predominately observed experimental results that substantial solids stratification during pipe flow and resulting non-homogenous conditions does not imply that a fixed solids bed will form within the piping system. Even if some gravitational stratification of the dispersed phase particulates occurs, observable solid particulates still are transported at velocities nearly equal to the carrier phase velocity (see Motyka and Randall 1976).

These findings emphasize the difficulty of predicting slurry flow behavior, particularly viewed in context of the complicated physical and chemical makeup of many of the Hanford wastes. Crowe et al. (1998) state:

The fluid mechanics of the liquid-solids flows is complex because of the particleparticle and fluid-particle interaction... The various correlations for head loss which have been developed for slurry flows can only be used with confidence for slurries with properties identical to those for which the correlations were obtained. Extrapolation of the correlations to other slurries may lead to. significant errors in pressure drop predictions. 
An example of this is provided by the Oroskar and Turian (1980) models, which were found to be the most thorough models considered. These state that conditions for achieving critical velocity in slurry flow are based on the assumption that turbulent flow is the present flow regime and that turbulent velocity fluctuations provide the source of energy by which a solid particulate is suspended. Not all researchers agree, however, that the turbulent flow regime is optimal for slurry transport (see Motyka and Randall 1976). In this reference, the researchers argue that laminar flow is optimal for slurry transport.

These conclusions indicate that the current tank farms waste transfer compatibility requirements of maintaining bulk flow with a Reynolds number in excess of 20,000 and a solids loading of less than $30 \mathrm{vol} \%$ does not ensure that a bulk flow velocity equivalent to the slurry flow critical velocity is achieved. The following replacement criteria is suggested:

If a waste transfer in tank farms is composed entirely of a liquid, no additional restrictions beyond the operating envelope of the transfer system need to be considered. If a waste transfer in tank farms plans or suspects that particulate solids will be entrained in or formed during the transfer, an analysis of the system flow conditions must be performed to assess a probability that transfer line plugging can be avoided. This will be accomplished by obtaining andior analyzing the following parameters:

1. The expected carrier liquid density.

2. The expected particulate solids density.

3. The expected slurry densities during the transfer.

4. The anticipated system flowrates at the expected slurry densities.

5. The particle size mass distribution or some other analytical measure such as the unhindered solids settling velocity from which an effective particulate solid diameter or diameter distribution can be obtained.

6. The expected carrier liquid viscosity or some other analytical measure such as the maximum expected slurry temperature during transfer from which the carrier liquid viscosity can be determined.

These six items provide the information upon which to base a justification for slurry transport via critical velocity analysis. The results of this analysis will be a semiquantitative estimate of the probability that, during waste transfer operations, solids deposition can be avoided. These results will form the basis for justifying an assessment of the probability of a successful slurry transfer. 


\subsection{REFERENCES}

Babcock, H. A., 1968, Chemical Engineering Review, 48(36).

Carothers, K. G., J. W. Bailey, S. D. Estey, N. W. Kirch, L. A. Stauffer, 1998, Tank 241-C-106 Waste Retrieval Stuicing System Process Control Plan, HNF-SD-WM-PCP-013, Revision 1, Fluor Daniel Hanford, Inc., Richland, Washington.

Castaing, B. A., 1994, 101-AY, 102-AY, and 106-C Data Compendium, WHC-SD-WM-TI-578, Rev. 1, Westinghouse Hanford Company, Richland, Washington.

Crowe, C. T., M. Sommerfeld, and Y. Tsuji, 1998, Multiphase Flows with Droplets and Particles, CRC Press LLC, Boca Raton, Florida.

Durand, R., 1953, Basic Relationships of the Transportation of Solids in Pipes Experimental Research, Proceedings, Minnesota International Hydraulics Convention, Minneapolis, Minnesota, pp. 89-103.

Edrington, R. S., 1988, Report on Characterization of 101-AY Tank Samples, (Internal Memorandum 12221-PCL88-169 to L. M. Bergman, July 20), Westinghouse Hanford Company, Richland, Washington.

Einstein, H. A., and Chien, N., 1955, Effects of Heavy Sediment Concentration near the Bed on Velocity and Sediment Distribution, University of California Institute of Engineering Research, M.S.D. Sediment Series, Report No. 8.

Ferrini, F., D. Ercolani, B. DeCindio, L. Nicodemo, L. Nicolais, S. Ranando, 1979, Shear Viscosity of Settling Suspensions, Rheologica Acta, 18, 289-296.

Herting, D. L., 1981, , Slurry Viscosities, (Internal Letter 65453-81-141 to D. G. Wilkins, April 27), Rockwell Hanford Operations, Richland, Washington.

Hudson J. D., 1996, Defining Waste Acceptance Criteria for the Hanford Replacement Cross-Site Transfer System, PNNL-1 1146, Pacific Northwest National Laboratory, Richland, Washington.

Liu, J., L. R. Pederson, and L. Q. Wang, 1995, Solid-Phase Characterization in Flammable-Gas-Tank Sludges by Electron Microscopy, PNL-10723, Pacific Northwest National Laboratory, Richland, Washington.

Lumetta, G. J., J. Liu, B. M. Rapko, Y. L. Chen, and M. J. Wagner, 1996, Washing and Caustic Leaching of Hanford Tank Sludges: Results of FY 1996 Studies, PNNL11278, Rev. 1, Pacific Northwest National Laboratory, Richland, Washington. 
Lumetta, G. J., I. E. Burgeson, M. J. Wagner, J. Liu, and Y. L. Chen, 1997, Washing and Caustic Leaching of Hanford Tank Sludges: Results of FY 1997 Studies, PNNL-11636, Rev. 1, Pacific Northwest National Laboratory, Richland, Washington.

Motyka, T., and C. T. Randall, 1976, Predicting Transport Requirements For. Radioactive Waste Slurries, E. I. Dupont de Nemours and Company.

Nguyen, Q. H., 1994, Summary of Tank Waste Physical Properties at the Hanford Site, WHC-EP-0756, Westinghouse Hanford Company, Richland, Washington.

Onishi, Y., and J. D. Hudson, 1996, Waste Mixing and Diluent Selection for the Planned Retrieval of Hanford Tank 241-SY-102: A Preliminary Assessment, PNNL-10927, Pacific Northwest National Laboratory, Richland, Washington.

Onishi, Y., R. Shekarriz, K. P. Recknagle, P. A. Smith, J. Liu, Y. L. Chen, D. R. Rector, and J. D. Hudson, 1996, Tank SY-102 Waste Retrieval Assessment: Rheological Measurements and Pump Jet Mixing Simulations, PNNL-11352, Pacific Northwest National Laboratory, Richland, Washington.

Oroskar, A. R., and R. M. Turian, 1980, The Critical Velocity in Pipeline Flow of Slurries, AIChE Journal , 26, pp 550-558.

Place, D. E., 1994, Project W-058/W-028 Slurry Transport Design Criteria, (Internal Memorandum 7E320-94-013 to D. V. Vo, October 31), Westinghouse Hanford Company, Richland, Washington.

Rapko, B. M., G. J. Lumetta, and M. J. Wagner, 1995, Washing and Caustic Leaching of Hanford Tank Sludges: Results of FY 1995 Studies, PNNL-10712, Pacific Northwest National Laboratory, Richland, Washington.

Rector, D. R., and B. C. Bunker, 1995, Effect of Colloidal Aggregation on the Sedimentation and Rheological Properties of Tank Waste, PNL-10761, Pacific Northwest National Laboratory, Richland, Washington.

Reynolds, D. A., 1988, Viscosity of Evaporator Slurries, (Internal Memo 13314-88-105 to M. C. Teats, June 30), Westinghouse Hanford Company, Richland, Washington.

Rodenhizer, D. G., 1987, Hanford Waste Tank Sluicing History, WHC-SD-WM-TI-756, Rev. 0, Westinghouse Hanford Company, Richland, Washington. 
Sathyanarayana K., 1994, Slurry Transport Design Review Calculations, (Internal Memorandum 7E880-94-KS-003 to D. V. Vo, September 21), Westinghouse Hanford Company, Richland, Washington.

Shah, S. N., and D. L. Lord, June 1991, Critical Velocity Correlations for Slurry Transport with Non-Newtonian Fluids, AIChE Journal Vol. 37, No. 6.

Shook, C. A., 1969, Pipelining Solids: The Design of Short-Distance Pipelines, Proceedings from the Symposium on Pipeline Transport of Solids, Canadian Society for Chemical Engineering, Toronto.

Shook, C. A. and M. C. Rocco, 1991, Slurry Flow-Principles and Practice, Butterworth-Heinemann, Stoneham, Massachusetts.

Sinclair, C. G., 1962, Proceedings from the Symposium on the Interaction Between Fluids and Particles, London, p.78.

Spells, 1955, Transcripts of the Institute of Chemical Engineers, London, 33, 79 - 84.

Temer, D. J., and R. Villarreal, 1997, Sludge Washing and Alkaline Leaching Tests on Actual Hanford Tank Sludge: FY 1997 Results, Los Alamos National Laboratory, Los Alamos, New Mexico.

Weast, R. C., and M. J. Astle, 1980, Handbook of Chemistry and Physics, $61^{\text {st }} \mathrm{Ed}$, CRC Press, Inc., Boca Raton, Florida

Zaltash, A., and M. R. Ally, 1992, Predicting Viscosities of Aqueous Salt Mixtures, CONF-921110 DE93 002421, 1992, ASME Winter Annual Meeting

Zandi, I, and G. Gavatos, 1967, Heterogeneous Flow of Solids in Pipelines, Journal of Hydraulics Division, ASCE, 93:(HY3), pp. 145-159. 
HNF-2728 Rev. 0

This page intentionally left blank. 
DISTRIBUTION SHEET

\begin{tabular}{|c|c|c|c|c|c|}
\hline \multirow[b]{2}{*}{ Distribution } & \multirow{2}{*}{\multicolumn{3}{|c|}{ Process Control }} & \multicolumn{2}{|l|}{ Page 1 of 2} \\
\hline & & & & \multicolumn{2}{|c|}{ Date $\quad 10 / 08 / 98$} \\
\hline \multicolumn{4}{|c|}{ Project Title/Work Order } & \multicolumn{2}{|c|}{ EDT No. EDT-622482 } \\
\hline \multicolumn{4}{|c|}{$\begin{array}{l}\text { HNF-2728, Rev, 0, "Flow Velocity Analysis for Avoidance of } \\
\text { Solids Deposition During Transport of Hanford Tank Waste } \\
\text { Slurries" }\end{array}$} & \multicolumn{2}{|c|}{ ECN No. $\mathrm{N} / \mathrm{A}$} \\
\hline Name & MSIN & $\begin{array}{l}\text { Text } \\
\text { With All } \\
\text { Attach. }\end{array}$ & Text Only & $\begin{array}{l}\text { Attach./ } \\
\text { Appendix } \\
\text { Only }\end{array}$ & $\begin{array}{c}\text { EDT/ECN } \\
\text { Only }\end{array}$ \\
\hline
\end{tabular}

Lockheed Martin Hanford Corp.

J. H. Baldwin

T. M. Blaak

S. D. Estey

K. D. Fowler

J. W. Hunt

N. W. Kirch

D. A. Reynolds

S. H. Rifaey

W. T. Thompson

ERC (Environmental Resource Center)

T.C.S.R.C.

H5- 03

S5-13

R2-11

$\mathrm{R} 2-11$

$\mathrm{R} 2-12$

R2-11

R2-11

RI -56

G3-21

R1-51

R1-10

$x$
$x$
$x$
$x$
$x$
$x$
$x$
$x$
$x$
$x$
5

Lockheed Martin Services Inc.

Centra7 Files B1-07 X

MACTC

B. B. Peters

H5-03 $\quad X$

Numatec Hanford Corp.

J. ATibert

K. A. Boes

P. J. Certa

J. S. Garfield

J. L. Gilbert

P. A. Haine

J. R. Jewett

J. W. Lentsch

R. P. Marsha 11, Jr.

T. H. May

P. Mouette

I. G. Papp

C. A. Rieck

J. E. Van Beek

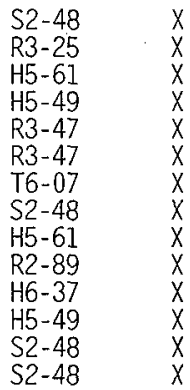

Pacific Northwest National Laboratory

J. A. Bamberger

c. W. Stewart

K7-15

K $7-15$

$x$
$x$

Scientific Applications International Corp.

W. G. Conn . 


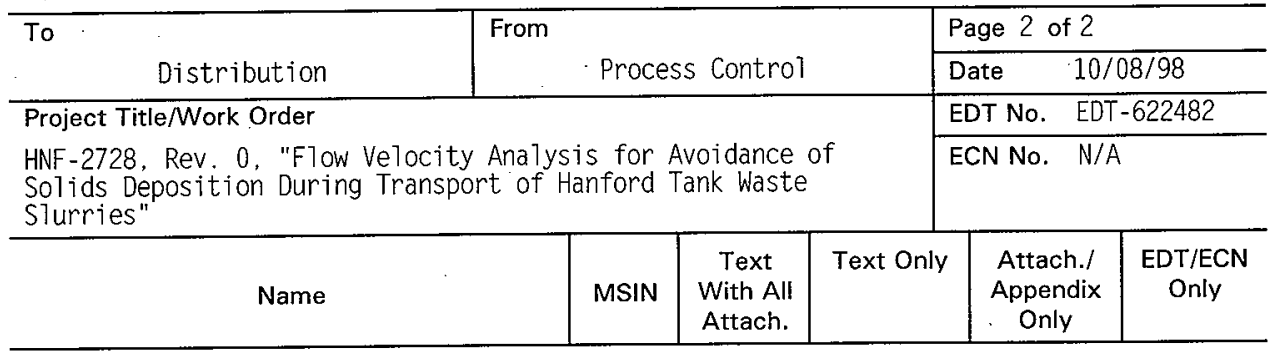

SGN Eurisys Services Corp.

G. T. MacLean

H5-27 $\quad X$

Waste Management Federal Services of Hanford Inc.

$\bar{B}$. H. Von Bargen

$56-72$

$x$

DOE/RL R.R.

$H 2.53 x$

